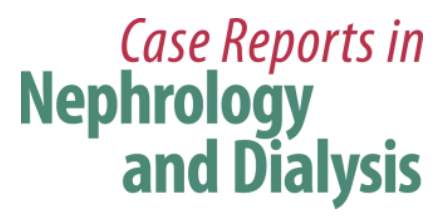

Case Rep Nephrol Dial 2018;8:82-89

DOI: $10.1159 / 000489088$

Published online: April 27, 2018

(c) 2018 The Author(s)

Published by S. Karger AG, Basel

www.karger.com/cnd

This article is licensed under the Creative Commons Attribution-NonCommercial 4.0 International License (CC BY-NC) (http://www.karger.com/Services/OpenAccessLicense). Usage and distribution for commercial purposes requires written permission.

\title{
Transcatheter Arterial Embolization Therapy for Huge Renal Cysts: Two Case Reports
}

Naoya Toriu ${ }^{a} \quad J^{\prime}$ nichi Hoshino ${ }^{a}$ Saeko Koboria Sun Watanabe Masahiko Oguro $^{a}$ Yoichi Oshima $^{a}$ Rikako Hiramatsu $^{a}$ Hiroki Mizuno $^{a}$ Daisuke Ikuma $^{a} \quad$ Akinari Sekine $^{a}$ Noriko Hayami $^{a}$ Keiichi Sumida ${ }^{a}$ Masayuki Yamanouchi ${ }^{a}$ Eiko Hasegawa ${ }^{a}$ Naoki Sawa ${ }^{a}$ Kenmei Takaichia,b Motoko Yanagitac ${ }^{c}$ Takuya Fujimaru ${ }^{d}$ Eisei Soharad Shinichi Uchida ${ }^{d}$ Yoshifumi Ubara ${ }^{a, b}$

aNephrology Center, Toranomon Hospital, Tokyo, Japan; ${ }^{b}$ Okinaka Memorial Institute for Medical Research, Tokyo, Japan; 'Department of Nephrology, Kyoto University Graduate School of Medicine, Kyoto, Japan; dDepartment of Nephrology, Graduate School of Medical and Dental Sciences, Tokyo Medical and Dental University, Tokyo, Japan

\section{Keywords}

Simple renal cyst $\cdot$ Transcatheter arterial embolization $\cdot$ Cyst drainage

\section{Abstract}

We encountered 2 patients with symptomatic huge simple renal cysts. In case 1, 4,000 mL of cyst fluid was drained via a catheter, but intracystic bleeding occurred immediately afterwards. Transcatheter arterial embolization (TAE) was performed, after which the bleeding stopped, and cyst drainage was repeated successfully. After 2 years, the total cyst volume was reduced from $11,775 \mathrm{~mL}$ to $75.4 \mathrm{~mL}$. In case 2, TAE was performed prophylactically before drainage. Subsequently, 9,400 $\mathrm{mL}$ of fluid was removed from multiple cysts. After 1 year, 


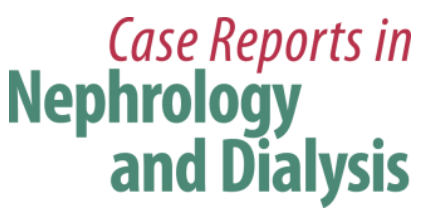

\begin{tabular}{l|l} 
Case Rep Nephrol Dial 2018;8:82-89 \\
\hline DOI: 10.1159/000489088 & $\begin{array}{l}\text { @ 2018 The Author(s). Published by S. Karger AG, Basel } \\
\text { www.karger.com/cnd }\end{array}$
\end{tabular}

Toriu et al.: Transcatheter Arterial Embolization Therapy for Huge Renal Cysts: Two Case Reports

the total cyst volume was reduced from $9,215 \mathrm{~mL}$ to $633 \mathrm{~mL}$ without bleeding. Based on these 2 cases, prophylactic TAE before drainage may be useful in patients with huge renal cysts.

(C) 2018 The Author(s)

Published by S. Karger AG, Basel

\section{Introduction}

Based on imaging findings, renal cysts are classified as simple (Bosniak categories I and II) or complex (Bosniak categories III and IV), with an intermediate category (Bosniak II-F) [1]. Simple renal cysts are benign and usually asymptomatic so that generally no treatment is required. If a simple cyst is symptomatic, percutaneous drainage is combined with sclerotherapy or surgical treatment is selected. In contrast, complex renal cysts are treated surgically because there is a high incidence of malignancy [2,3].

We encountered 2 patients with huge simple renal cysts that were symptomatic. Severe intracystic bleeding occurred after cyst drainage in the first patient and was successfully treated by transcatheter arterial embolization (TAE). In the second patient, TAE was performed prophylactically, and there was no bleeding associated with subsequent cyst drainage. We discuss the therapeutic options for huge renal cysts based on these 2 cases.

\section{Case Reports}

\section{Case 1}

In August 2007, a 24-year-old Japanese woman was admitted to an outside hospital for investigation of abdominal pain and distension. Contrast-enhanced computed tomography (CT) revealed a huge homogeneous cyst $(50 \times 25 \times 18 \mathrm{~cm} ; 11,775 \mathrm{~mL})$ in the right kidney. The cyst walls were thin, and the lesion was sharply delineated from the renal parenchyma, so it was categorized as a category I cyst according to the Bosniak classification [1] (Fig. 1a). Percutaneous catheter drainage was performed under ultrasonographic guidance. Immediately after $4,000 \mathrm{~mL}$ of cyst fluid was removed, the patient developed severe abdominal pain and her hemoglobin decreased from $11.0 \mathrm{~g} / \mathrm{dL}$ to $7.3 \mathrm{~g} / \mathrm{dL}$. Therefore, further cyst drainage and sclerotherapy were not done. CT revealed intracystic bleeding (Fig. 1b). She received transfusion of packed red blood cells $(800 \mathrm{~mL})$. Nephrectomy was recommended, but the patient hoped to preserve her kidney and was referred to our hospital to explore further options.

On admission, she was $157 \mathrm{~cm}$ tall and weighed $47.5 \mathrm{~kg}$, with a blood pressure of 98/56 $\mathrm{mm} \mathrm{Hg}$, heart rate of $105 / \mathrm{min}$, and body temperature of $37.5^{\circ} \mathrm{C}$. Laboratory findings were as follows (Table 1): white blood cell count, 12,900/ $\mu \mathrm{L}$; red blood cell count, $3.10 \times 10^{6} / \mu \mathrm{L}$; hemoglobin, $8.6 \mathrm{~g} / \mathrm{dL}$; platelet count, $339 \times 10^{3} / \mu \mathrm{L}$; total protein, $6.3 \mathrm{~g} / \mathrm{dL}$; albumin, 1.8 $\mathrm{g} / \mathrm{dL}$; blood urea nitrogen, $3 \mathrm{mg} / \mathrm{dL}$; serum creatinine (Cre), $0.4 \mathrm{mg} / \mathrm{dL}$; and C-reactive protein (CRP), $15.6 \mathrm{mg} / \mathrm{dL}$. 


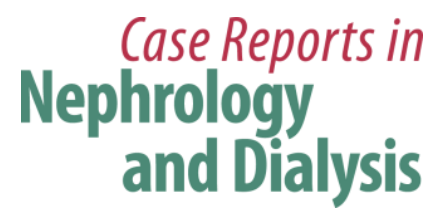

Case Rep Nephrol Dial 2018;8:82-89

DOI: $10.1159 / 000489088$

(C) 2018 The Author(s). Published by S. Karger AG, Basel www.karger.com/cnd

Toriu et al.: Transcatheter Arterial Embolization Therapy for Huge Renal Cysts: Two Case Reports

\section{Clinical Course}

The patient gave informed consent to renal TAE rather than other therapeutic options. Angiography showed elongated and narrow branches of the right renal artery encircling the huge cyst (Fig. 1c). TAE was performed using 28 platinum microcoils according to the previously reported method [4,5], achieving occlusion of the feeding arteries while preserving the residual right kidney parenchyma (Fig. 1d). After TAE, intracystic bleeding stopped and percutaneous catheter drainage was again performed under ultrasonographic guidance, removing 4,000 $\mathrm{mL}$ of bloody fluid. Further hemorrhage did not occur. Two years later, her cyst was reduced to dimensions of $6 \times 4 \times 4 \mathrm{~cm}$ with a volume of $75.4 \mathrm{~mL}$ (Fig. 1e).

\section{Case 2}

In July 2016, a 16-year-old Japanese female was admitted to our hospital with abdominal distention. CT revealed 4 huge cysts in the left kidney, while the right kidney was normal. The total volume of the 4 cysts was $9,215 \mathrm{~mL}$, and all cysts were Bosniak category I (Fig. 2a, b). Although nephrectomy had been recommended at the previous hospital where she was first assessed, both the patient and her parents preferred to avoid surgery and wanted to explore further therapeutic options.

On admission, she was $155.1 \mathrm{~cm}$ tall and weighed $56.5 \mathrm{~kg}$, with a blood pressure of $124 / 87 \mathrm{~mm} \mathrm{Hg}$ and body temperature of $36.5^{\circ} \mathrm{C}$. Abdominal distention was noted. Laboratory findings were as follows (Table 1 ): white blood cell count, $4,200 / \mu \mathrm{L}$; red blood cell count, $3.94 \times 10^{6} / \mu \mathrm{L}$; hemoglobin, $12.2 \mathrm{~g} / \mathrm{dL}$; platelet count, $284 \times 10^{3} / \mu \mathrm{L}$; total protein, $7.1 \mathrm{~g} / \mathrm{dL}$; albumin, $4.5 \mathrm{~g} / \mathrm{dL}$; blood urea nitrogen, $5.3 \mathrm{mg} / \mathrm{dL}$; Cre, $0.63 \mathrm{mg} / \mathrm{dL}$; and CRP, $0 \mathrm{mg} / \mathrm{dL}$. Genetic testing was performed (including PKD1 and PKD2) according to the previous method [6], but no abnormalities were detected.

\section{Clinical Course}

Because intracystic bleeding had occurred in case 1 after catheter drainage, prophylactic TAE was performed in this patient to avoid bleeding. A total of 8 platinum microcoils were used to block the branches of the left renal artery encircling the cyst walls (Fig. 2c, d). Subsequently, a total volume of $9,400 \mathrm{~mL}$ of cyst fluid was removed. Then, sclerotherapy was performed by daily infusion of minocycline hydrochloride for 7 days and the catheters were removed. Cytology for the cystic fluid was negative for malignancy. Serum Cre increased to $0.93 \mathrm{mg} / \mathrm{dL}$ immediately after TAE, but then improved to $0.63 \mathrm{mg} / \mathrm{dL}$ within 1 week. After 1 year, the total cyst volume was decreased to $633 \mathrm{~mL}$ (Fig. 2e).

\section{Discussion}

The cases reported here illustrate 2 main clinical issues: (1) percutaneous catheter drainage of huge cysts is associated with a risk of severe intracystic hemorrhage, and (2) prophylactic TAE can be employed to prevent such hemorrhage.

Symptomatic renal cysts (simple or complicated) can be treated by percutaneous catheter drainage plus sclerotherapy or by surgery, depending on the risk of malignancy. Bosniak classified renal cysts into 5 categories (I, II, II-F, III, and IV) according to their complexity and the likelihood of malignancy [1]. The risk of malignancy is negligible for renal cysts in cate- 


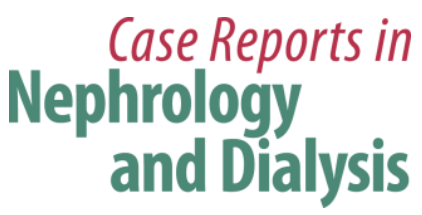

Case Rep Nephrol Dial 2018;8:82-89

gories I or II, so percutaneous drainage is performed if a cyst is symptomatic. Renal cysts in category II-F are suspicious for malignancy, so regular follow-up is recommended with percutaneous drainage if the cyst is symptomatic. On the other hand, there is a higher risk of malignancy for cysts in categories III or IV, so these lesions are managed by surgical resection [3].

Methods that have been reported for reducing the size of large renal cysts include drainage (needle aspiration) and sclerotherapy, as well as surgical and laparoscopic fenestration. Atug et al. [7] performed laparoscopic decortication of symptomatic simple renal cysts in 45 patients whose mean cyst size was $9.7 \mathrm{~cm}$ in diameter and among whom 24 patients $(53.3 \%)$ had undergone previous cyst aspiration with injection of a sclerosant. Only 1 patient $(2.2 \%)$ required conversion to open surgery because of excessive bleeding, and laparoscopic decortication was considered to be an effective and durable option for symptomatic simple renal cysts. They also suggested that cyst aspiration was associated with a high recurrence rate, although percutaneous drainage is safe and minimally invasive. Kilinc et al. [8] treated 76 symptomatic cysts, whose mean cyst size was $6.9 \mathrm{~cm}$, by aspiration with or without sclerotherapy and concluded that aspiration with sclerotherapy was more effective without any major complications. In addition, Akinci et al. [9] treated 98 simple renal cysts by percutaneous sclerotherapy, achieving an average cyst volume reduction of $93 \%$ at 1 year. Although 1 patient developed spontaneous cyst hemorrhage 1 year after the procedure, treatment was not required. Moreover, Fontana et al. [10] performed percutaneous drainage followed by 3 consecutive injections of alcohol for 72 renal cysts measuring 9-14 $\mathrm{cm}$ in diameter (mean, $10.8 \mathrm{~cm}$ ), achieving complete obliteration of the cyst cavity in 68 patients, although 1 patient developed cyst hemorrhage and required surgical treatment without the need for blood transfusion.

The safety of draining huge renal cysts has not yet been established, because there have only been a few reports about drainage of cysts measuring more than $15 \mathrm{~cm}$ in diameter. Riyach et al. [11] reported the removal of $8 \mathrm{~L}$ of fluid from a giant cyst $(35 \times 32 \times 22 \mathrm{~cm})$ with no major complications.

In our 2 cases, we found that performing TAE for the feeding arteries of the cysts could prevent or treat intracystic bleeding related to drainage and also reduced the cyst size. There have been no previous reports about treatment of simple renal cysts by TAE, although renal TAE is employed for autosomal dominant polycystic kidney disease. In patients with this disease, the renal cysts are usually supplied by well-developed arteries with an extensive capillary network so that hemorrhage is frequent [5], and TAE has been reported to be effective for intracystic bleeding [4]. Furthermore, Fujisaki et al. [12] treated patients with horseshoe kidney and persistent abdominal fullness after commencement of hemodialysis by embolizing only the right renal artery to maintain residual kidney function and reported involution of the right part of the kidney with preservation of urine output after 2 years. Finally, Ubara [13] reported that TAE could reduce the kidney size in patients with a symptomatic nonfunctioning hydronephrotic kidney.

Drainage of huge cysts without potentially prophylactic TAE may lead to massive bleeding of the simple cysts. It has been suggested that drainage of huge cysts may cause sudden shrinkage of the cysts, which may denature the blood vessels of the cysts, and the blood flow of arteries which supply the cysts is stopped so that intracystic bleeding occurs. On the other hand, adverse events, including contrast-induced nephropathy and cholesterol embolization, 


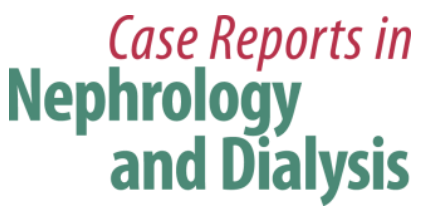

\begin{tabular}{l|l} 
Case Rep Nephrol Dial 2018;8:82-89 \\
\hline DOI: 10.1159/000489088 & $\begin{array}{l}\text { @ } 2018 \text { The Author(s). Published by S. Karger AG, Basel } \\
\text { www.karger.com/cnd }\end{array}$
\end{tabular}

should be considered. The risk factors of contrast-induced nephropathy are preexisting chronic kidney disease, diabetes mellitus, older age, and dehydration, while those of cholesterol embolization are older age, hypertension, diabetes mellitus, and atherosclerotic vascular disease $[14,15]$. Adverse events should be considered if the patients have these risk factors.

In conclusion, we managed 2 patients with huge simple renal cysts. Severe intracystic bleeding occurred after cyst drainage in case 1 . Angiography showed well-developed feeding vessels arising from the renal artery to supply the cyst, and TAE targeting these vessels prevented further bleeding. TAE was performed prophylactically in case 2 to prevent intracystic bleeding, after which cyst drainage was accomplished successfully without hemorrhage. Our experience suggests that it may be worth considering prophylactic TAE as an option before drainage of huge renal cysts.

\section{Statement of Ethics}

The present study adhered to the Declaration of Helsinki, and both patients gave consent for the details of their cases to be published.

\section{Disclosure Statement}

The authors declare no competing financial interests. The authors also declare that they have no conflicts of interest.

\section{References}

1 Muglia VF, Westphalen AC. Bosniak classification for complex renal cysts: history and critical analysis. Radiol Bras. 2014 Nov-Dec;47(6):368-73.

2 Desai D, Modi S, Pavicic M, Thompson M, Pisko J. Percutaneous Renal Cyst Ablation and Review of the Current Literature. J Endourol Case Rep. 2016 Feb;2(1):11-3.

3 Agarwal MM, Hemal AK. Surgical management of renal cystic disease. Curr Urol Rep. 2011 Feb;12(1):3-10.

4 Suwabe T, Ubara Y, Sumida K, Hayami N, Hiramatsu R, Yamanouchi M et al. Clinical features of cyst infection and hemorrhage in ADPKD: new diagnostic criteria. Clin Exp Nephrol. 2012 Dec;16(6):892-902.

5 Ubara Y, Tagami T, Sawa N, Katori H, Yokota M, Takemoto F et al. Renal contraction therapy for enlarged polycystic kidneys by transcatheter arterial embolization in hemodialysis patients. Am J Kidney Dis. 2002 Mar;39(3):571-9.

6 Fujimaru T, Mori T, Sekine A, Mandai S, Chiga M, Kikuchi H et al. Kidney enlargement and multiple liver cyst formation implicate mutations in PKD1/2 in adult sporadic polycystic kidney disease. Clin Genet. 2018 Mar 9. doi: 10.1111/cge.13249.

7 Atug F, Burgess SV, Ruiz-Deya G, Mendes-Torres F, Castle EP, Thomas R. Long-term durability of laparoscopic decortication of symptomatic renal cysts. Urology. 2006 Aug;68(2):272-5.

8 Kilinc M, Tufan O, Guven S, Odev K, Gurbuz R. Percutaneous injection sclerotherapy with tetracycline hydrochloride in simple renal cysts. Int Urol Nephrol. 2008;40(3):609-13.

9 Akinci D, Akhan O, Ozmen M, Gumus B, Ozkan O, Karcaaltincaba M et al. Long-term results of single-session percutaneous drainage and ethanol sclerotherapy in simple renal cysts. Eur J Radiol. 2005 May;54(2):298302.

10 Fontana D, Porpiglia F, Morra I, Destefanis P. Treatment of simple renal cysts by percutaneous drainage with three repeated alcohol injection. Urology. 1999 May;53(5):904-7. 


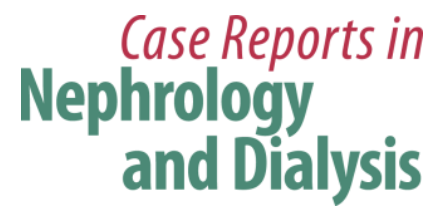

\begin{tabular}{l|l} 
Case Rep Nephrol Dial 2018;8:82-89 \\
\hline DOI: 10.1159/000489088 & $\begin{array}{l}\text { (c) 2018 The Author(s). Published by S. Karger AG, Basel } \\
\text { www.karger.com/cnd }\end{array}$
\end{tabular}

11 Riyach 0, Ahsaini M, Tazi K, Tazi MF, Mellas S, El Ammari JE et al. A huge renal cyst mimicking ascites: a case report. BMC Res Notes. 2014 Jan;7(1):39.

12 Fujisaki A, Ubara Y, Suwabe T, Hoshino J, Nakanishi S, Yamanouchi M et al. Transarterial renal embolization for enlarged horseshoe kidney. Clin Exp Nephrol. 2010 Apr;14(2):180-4.

13 Ubara Y. New therapeutic option for autosomal dominant polycystic kidney disease patients with enlarged kidney and liver. Ther Apher Dial. 2006 Aug;10(4):333-41.

14 Ozkok S, Ozkok A. Contrast-induced acute kidney injury: A review of practical points. World J Nephrol. 2017 May;6(3):86-99.

15 Scolari F, Ravani P. Atheroembolic renal disease. Lancet. 2010 May;375(9726):1650-60.

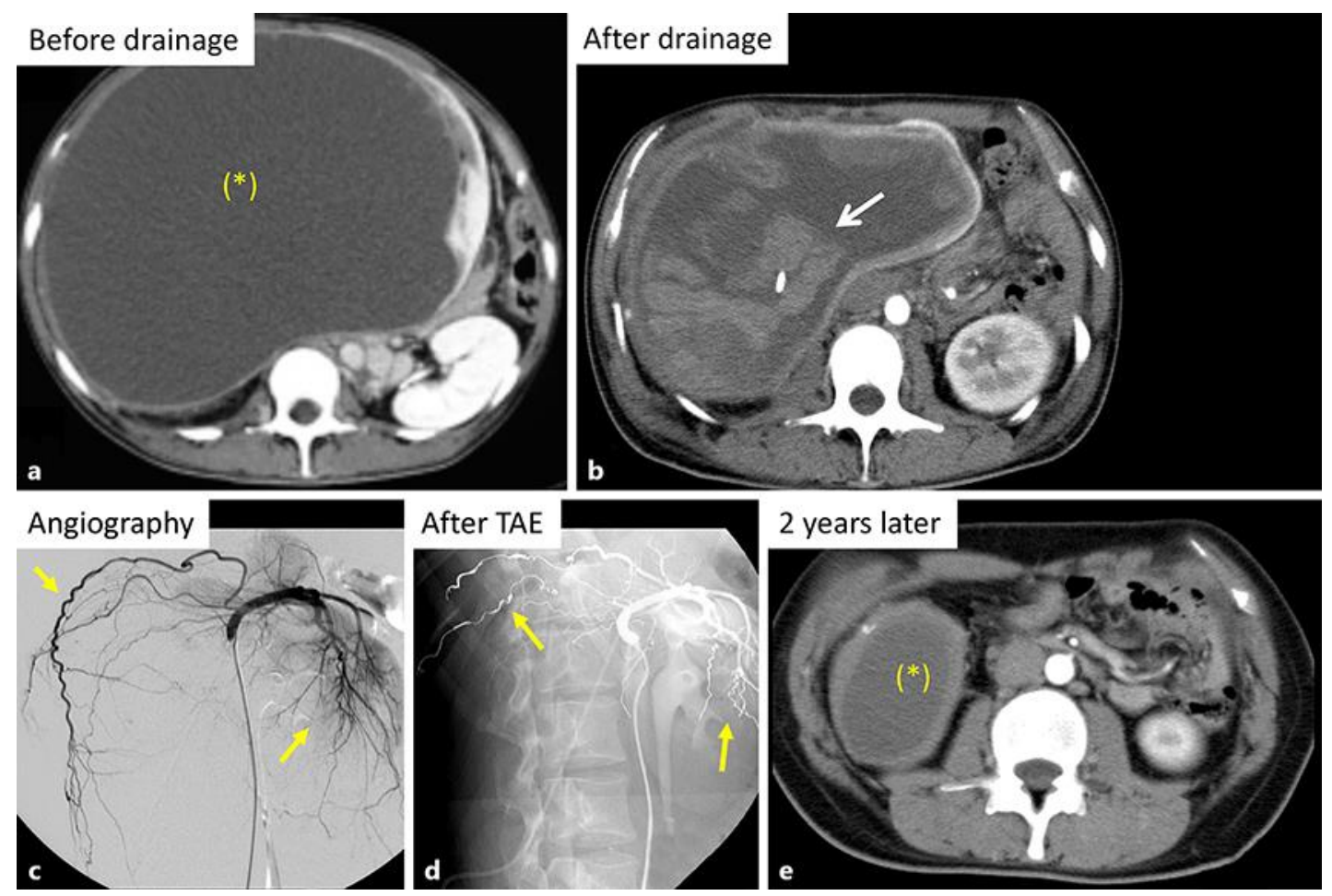

Fig. 1. Case 1. a Contrast-enhanced CT reveals a huge renal cyst (*) before drainage. b Contrast-enhanced CT shows intracystic bleeding (arrow) after initial drainage of the cyst. c Renal artery angiography displays well-developed feeding arteries supplying the renal cyst (arrows). d Radiograph shows microcoils (arrows) after TAE. e CT reveals involution of the cyst $\left({ }^{*}\right)$ after treatment. CT, computed tomography; TAE, transcatheter arterial embolization. 

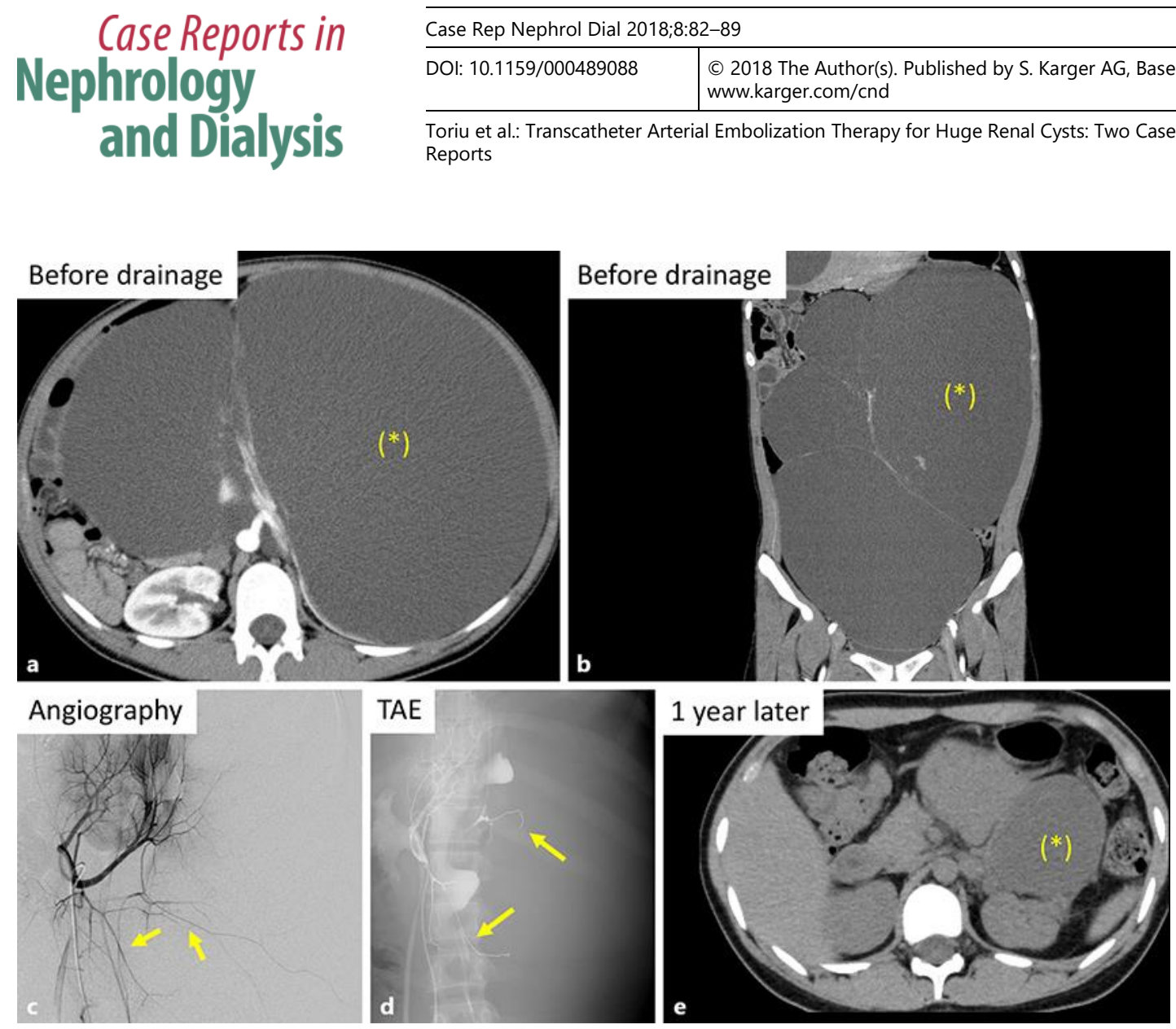

Fig. 2. Case 2. a Axial contrast-enhanced CT shows 4 huge renal cysts in the left kidney. (*) indicates the largest cyst. b On coronal CT, huge cysts occupy the abdominal cavity. ( ${ }^{*}$ ) indicates the largest cyst. c Renal artery angiography reveals well-developed feeding arteries supplying the renal cysts (arrows). d Radiograph shows microcoils (arrows) after TAE. e CT displays involution of the largest cyst (*) after treatment. CT, computed tomography; TAE, transcatheter arterial embolization. 

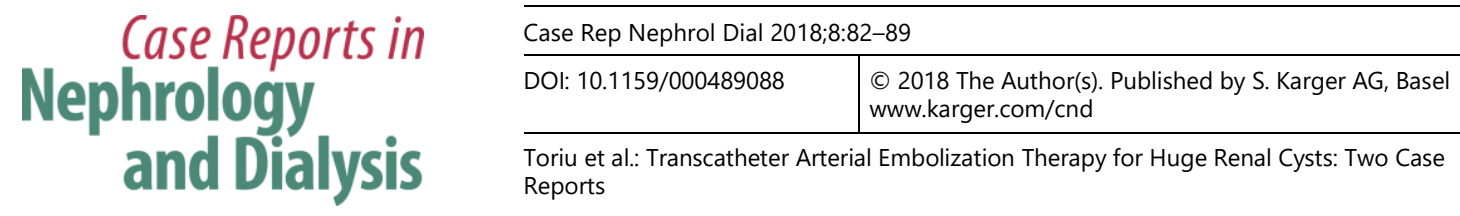

Toriu et al.: Transcatheter Arterial Embolization Therapy for Huge Renal Cysts: Two Case Reports

Table 1. Laboratory findings

\begin{tabular}{|c|c|c|c|c|}
\hline & Unit of measurement & Case 1 & Case 2 & Normal range \\
\hline White blood cells & $/ \mu \mathrm{L}$ & 12,900 & 4,200 & $3,200-7,900$ \\
\hline Hemoglobin & $\mathrm{g} / \mathrm{dL}$ & 8.6 & 12.2 & $11.3-15.0$ \\
\hline Platelets & $\times 10^{3} / \mu \mathrm{L}$ & 339 & 284 & $155-350$ \\
\hline Total protein & $\mathrm{g} / \mathrm{dL}$ & 6.3 & 7.1 & $6.9-8.4$ \\
\hline Albumin & $\mathrm{g} / \mathrm{dL}$ & 1.8 & 4.5 & $3.9-5.2$ \\
\hline AST & IU/L & 20 & 24 & $13-33$ \\
\hline ALT & IU/L & 13 & 23 & $117-350$ \\
\hline $\mathrm{LDH}$ & IU/L & 101 & 220 & $119-229$ \\
\hline ALP & IU/L & 237 & 310 & $117-350$ \\
\hline$\gamma$-GTP & IU/L & 13 & 21 & $9-109$ \\
\hline Urea nitrogen & $\mathrm{mg} / \mathrm{dL}$ & 3 & 5.3 & $8-21$ \\
\hline Creatinine & $\mathrm{mg} / \mathrm{dL}$ & 0.4 & 0.63 & $0.46-0.78$ \\
\hline eGFR & $\mathrm{mL} / \mathrm{min} / 1.73 \mathrm{~m}^{2}$ & 156.9 & 107.2 & $>90$ \\
\hline Uric acid & $\mathrm{mg} / \mathrm{dL}$ & 1.4 & 5.3 & $2.5-7.0$ \\
\hline $\mathrm{Na}$ & $\mathrm{mmol} / \mathrm{L}$ & 139 & 141 & $139-146$ \\
\hline $\mathrm{K}$ & $\mathrm{mmol} / \mathrm{L}$ & 3.9 & 3.8 & $3.7-4.8$ \\
\hline $\mathrm{Cl}$ & $\mathrm{mmol} / \mathrm{L}$ & 103 & 104 & $101-109$ \\
\hline $\mathrm{Ca}$ & $\mathrm{mg} / \mathrm{dL}$ & 7.6 & 9.6 & $8.7-10.1$ \\
\hline $\mathrm{P}$ & $\mathrm{mg} / \mathrm{dL}$ & 3.1 & 4.9 & $2.8-4.6$ \\
\hline Bil & $\mathrm{mg} / \mathrm{dL}$ & 0.4 & 0.7 & $0.3-1.1$ \\
\hline CRP & $\mathrm{mg} / \mathrm{dL}$ & 15.6 & 0 & $0.0-0.3$ \\
\hline PT & $\%$ & 70.1 & 95.6 & $>75$ \\
\hline APTT & $\mathrm{s}$ & 29.2 & 28.4 & $27.0-40.0$ \\
\hline
\end{tabular}

AST, aspartate transaminase; ALT, alanine transaminase; LDH, lactate dehydrogenase; ALP, alkaline phosphatase; $\gamma$-GTP, gamma glutamyl transferase; eGFR, estimated glomerular filtration rate; Bil, bilirubin; CRP, C-reactive protein; PT, prothrombin time; APTT, activated partial thromboplastin time. 